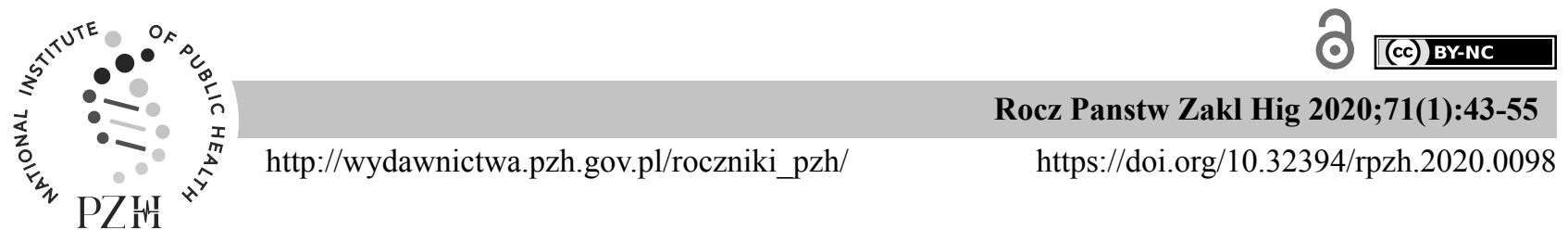

\title{
“CLEAN LABEL" AS ONE OF THE LEADING TRENDS IN THE MEAT INDUSTRY IN THE WORLD AND IN POLAND - A REVIEW
}

\author{
Aneta Cegietka ${ }^{1}$ \\ ${ }^{1}$ Institute of Food Sciences, Warsaw University of Life Sciences - WULS (SGGW), Warsaw, Poland
}

\begin{abstract}
The contemporary market of food products is highly variable. The reason for this is, among others the significant number of factors governing consumer choices in relation to food. Research results indicate that Polish consumers are increasingly declaring their interest in food features such as sensory and health properties, and safety. Most likely, social education, campaigns of food societies and own initiatives of food producers promoting new, "healthy" products have contributed to this. Among other things, the ever increasing consumer knowledge on the relationship between lifestyle and diet and health has become for many food businesses prerequisite for the development and marketing of new products. In food production in the world and in Poland the so-called "clean label" trend is one of fastest growing initiatives aimed at improving the health quality of foods. The "clean label" has not yet been defined in food law and is understood rather subjectively. Generally, this term is attributed to products free from "artificial" additives and produced by "natural" or based on a traditional recipe methods known to consumers. In the article, based on the available literature, selected trends in food production at the beginning of the 21st century, with particular emphasis on "clean label" have been discussed. Taking meat processing industry as an example, the measures undertaken by the companies of food industry to produce "clean label" food products have been illustrated. In addition, consumer attitudes toward contemporary trends in the food market, including meat and meat products, have been characterized. In conclusion, the need for legislative intervention to provide appropriate definition for the term "clean label" and the need for consumer education about assessment of quality of foods are emphasized.
\end{abstract}

Key words: clean label, food additives, food labeling, health, meat products, legislation

\section{STRESZCZENIE}

Współczesny rynek produktów spożywczych jest bardzo zmienny. Powodem tego jest między innymi znaczna liczba czynników rządzących wyborami konsumenckimi w odniesieniu do żywności. Wyniki badań wskazują, że polscy konsumenci coraz częściej deklarują swoje zainteresowanie cechami żywności, takimi jak właściwości sensoryczne oraz bezpieczeństwo i zdrowotne. Najprawdopodobniej przyczyniła się do tego edukacja społeczna, kampanie towarzystw żywnościowych i własne inicjatywy producentów żywności promujące nowe, „zdrowe” produkty. Między innymi stale rosnąca wiedza konsumentów na temat związku między stylem życia a dietą i zdrowiem stała się dla wielu firm spożywczych warunkiem rozwoju i wprowadzania na rynek nowych produktów. W produkcji żywności na świecie i w Polsce trend tzw. „czystej etykiety” jest jedną z najszybciej rozwijających się inicjatyw mających na celu poprawę jakości zdrowotnej żywności. „Czysta etykieta” nie została jeszcze zdefiniowana w prawie żywnościowym i jest rozumiana raczej subiektywnie. Ogólnie termin ten przypisuje się produktom wolnym od „sztucznych” dodatków i wytwarzanym „naturalnymi” metodami lub opartymi na tradycyjnych recepturach znanych konsumentom. W artykule na podstawie dostępnej literatury omówiono wybrane trendy w produkcji żywności na początku XXI wieku, ze szczególnym uwzględnieniem „czystej etykiety”. Biorąc za przykład przemysł przetwórstwa mięsa, zilustrowano działania podejmowane przez firmy $\mathrm{z}$ branży spożywczej $\mathrm{w}$ celu wyprodukowania produktów spożywczych, które mogłyby zostać opatrzone „czystą etykietą”. Ponadto scharakteryzowano postawy konsumentów wobec współczesnych trendów na rynku żywności, w tym mięsa i produktów mięsnych. Podsumowując, podkreślono potrzebę interwencji legislacyjnej w celu zapewnienia właściwej definicji terminu „czysta etykieta” oraz potrzebę edukacji konsumentów na temat oceny jakości żywności.

Slowa kluczowe: czysta etykieta, dodatki do żywności, etykietowanie żywności, zdrowie, produkty mięsne, ustawodawstwo

Corresponding author: Aneta Cegiełka, Institute of Food Sciences, Warsaw University of Life Sciences (WULS - SGGW), Nowoursynowska St. 159c, 02-787 Warsaw, Poland; tel.: +48 2259375 32, e-mail: aneta_cegielka@sggw.pl 


\section{INTRODUCTION}

Marketing trends are the basis for planning and making decisions for every industry, and this is also applicable for food sector companies. A keen observation of the marketing activities is extremely important as the modern food market is subjected to continuous fluctuations. The reason for this variation is, among others, increasing diversity in the needs of consumers and a considerable number of factors influencing the consumer choices of food products [5].

As a consequence of the globalization process, the Polish food industry, including the meat industry, has become an integral part of an open global economic system. This means that industry is constantly subjected to strong competitive pressure and needs to be modified to meet the demand. Native producers successfully undertake many measures to maintain the quality of agri-food products according to global standards and take advantage of market niches. They are very flexible and their activities are modified according to the current trends prevailing in the world food market [5].

One of the fastest-growing agricultural sectors in Poland is meat production [85]. The meat products have played a crucial role in human evolution. Till date, they continue to be an important component of a wellbalanced and mixed diet due to the presence of rich nutrients $[13,53,83]$. The importance of meat industry in Poland is evidenced by the fact that producers of meat and meat products constitute one of the three largest groups of companies in the food sector, in addition to alcohol producers and dairy industries. It is estimated that in 2018, Poland has produced 2,350 thousand tons of poultry meat, 1,957 thousand tons of pork, and 580 thousand tons of beef [85]. The statistical data with regard to the consumption of meat in the culinary form and as meat preparations for several years has indicated that each person consumes close to or exceeding $70 \mathrm{~kg}$ of meat per year [30]. However, like the other branches of the food industry, the meat industry must adapt to current market changes to increase sales. These changes are largely shaped by consumer requirements and new market trends.

The aim of this study was to review research concerning new trends in food production in the world and in Poland aimed at improving the health quality of food, especially the "clean label" trend. Taking meat processing industry as an example, the measures undertaken by the companies of food industry to produce food products with "clean label" have been illustrated. In addition, consumer attitudes toward contemporary trends in the food market, including meat and meat products, have been briefly characterized.

\section{"CLEAN LABEL" AND OTHER TRENDS ADOPTED IN THE PRODUCTION OF MEAT AND MEAT PRODUCTS AND CONSUMER ATTITUDES}

The new trends adopted in food production, which on the one hand aim to meet the growing demand for food and on the other hand adapting the product to the new requirements of consumers, are presented in Figure 1. The trends concerning the production of the so-called "clean label" products are also included in this article.

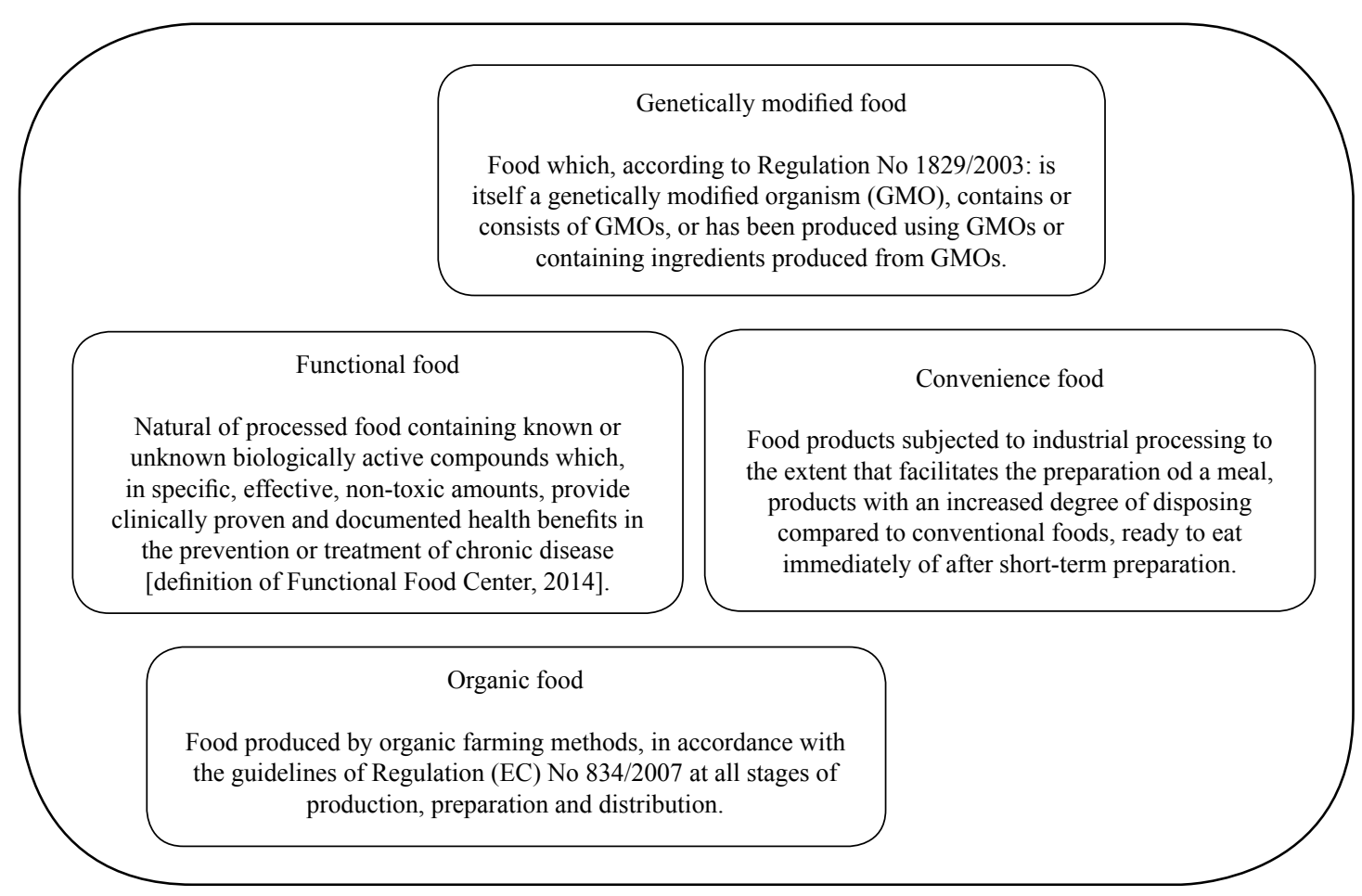

Figure 1. Selected trends in food production in the world and in Poland in the 21st century $[8,9,33,34,44,94]$ 
As many aspects of food production are regulated by law in European Union (EU), the selected acts of food law referring to the issues raised in this article have been summarized in Table 1 .

Table 1. Selected legal acts regarding food safety and labeling, use of food additives, organic farming, and production of novel and genetically modified foods

\begin{tabular}{|c|c|}
\hline Regulated food production areas & Title of legal act \\
\hline Food safety & $\begin{array}{l}\text { - Regulation (EC) } \mathbf{1 7 8 / 2 0 0 2} \text { of the European Parliament and the Council of } 28 \\
\text { January } 2002 \text { laying down the general principles and requirements of food law, } \\
\text { appointing the European Food Safety Authority, and laying down the procedures } \\
\text { concerning food safety. Off J EU L } 31,1.2 .2002 \text {. } \\
\text { Ustawa z dnia } 25 \text { sierpnia } 2006 \text { r. o bezpieczeństwie żywności i żywienia. Dz U } \\
2017 \text { r. poz. } 149 \text {. }\end{array}$ \\
\hline Food labeling & $\begin{array}{l}\text { - Regulation (EC) No 1924/2006 of the European Parliament and of the Council } \\
\text { of } 20 \text { December } 2006 \text { on nutrition and health claims made on foods. Off J EU L } \\
\text { 404, 30.12.2006. } \\
\text { Regulation (EU) No 1169/2011 of the European Parliament and of the Council } \\
\text { of } 25 \text { October } 2011 \text { on the provision of food information to consumers, } \\
\text { amending Regulations (EC) No } 1924 / 2006 \text { and (EC) No } 1925 / 2006 \text { of the } \\
\text { European Parliament and of the Council, and repealing Commission Directive } \\
\text { 87/250/EEC, Council Directive 90/496/EEC, Commission Directive } 1999 / 10 / \\
\text { EC, Directive 2000/13/EC of the European Parliament and of the Council, } \\
\text { Commission Directives 2002/67/EC and 2008/5/EC and Commission } \\
\text { Regulation (EC) No 608/2004. Off J EU L 304, 22.11.2011. } \\
\text { - Ustawa z dnia } 4 \text { listopada } 2016 \mathrm{r} \text { o zmianie ustawy o jakości handlowej } \\
\text { artykułów rolno-spożywczych. Dz U } 2016 \text { poz. } 2007 \text {. } \\
\text { - Rozporządzenie Ministra Rolnictwa i Rozwoju Wsi z dnia } 16 \text { grudnia } 2016 \mathrm{r} \text {. } \\
\text { W sprawie wzoru znaku graficznego zawierającego informację "Produkt polski". } \\
\text { Dz U 2016, poz. } 2148 \text {. }\end{array}$ \\
\hline Use of food additives & $\begin{array}{l}\text { - Regulation (EC) No } \mathbf{1 3 3 3 / 2 0 0 8} \text { of the European Parliament and of the Council } \\
\text { of } 16 \text { December } 2008 \text { on food additives. Off J EU L354, 31.12.2008. } \\
\text { - Commission Regulation (EU) No 1129/2011 of } 11 \text { November } 2011 \text { amending } \\
\text { Annex II to Regulation (EC) No } 1333 / 2008 \text { of the European Parliament and } \\
\text { of the Council by establishing a Union list of food additives. Off J EU L 295, } \\
\text { 12.11.2011. }\end{array}$ \\
\hline Organic farming and organic foods & $\begin{array}{l}\text { - Ustawa z dnia } 25 \text { czerwca } 2009 \text { r. o rolnictwie ekologicznym. Dz U } 2009 \mathrm{nr} \\
116 \text { poz. } 975 \text {. } \\
\text { Regulation (EU) 2018/848 of the European Parliament and of the Council of } 30 \\
\text { May } 2018 \text { on organic production and labeling of organic products and repealing } \\
\text { Council Regulation (EC) No 834/2007. Off J EU L 150, 14.6.2018. }\end{array}$ \\
\hline Novel foods & $\begin{array}{l}\text { Regulation (EU) } \mathbf{2 0 1 5} / \mathbf{2 2 8 3} \text { of the European Parliament and of the Council of } \\
25 \text { November } 2015 \text { on novel foods, amending Regulation (EU) No } 1169 / 2011 \\
\text { of the European Parliament and of the Council and repealing Regulation (EC) } \\
\text { No 258/97 of the European Parliament and of the Council and Commission } \\
\text { Regulation (EC) No 1852/2001. Off J EU L 327, 11.12.2015. }\end{array}$ \\
\hline Genetically modified foods & $\begin{array}{l}\text { Regulation (EC) No } \mathbf{1 8 2 9} / \mathbf{2 0 0 3} \text { of the European Parliament and of the Council } \\
\text { of } 22 \text { September } 2003 \text { on genetically modified food and feed. Off J EU L 268, } \\
\text { 18.10.2003. }\end{array}$ \\
\hline
\end{tabular}

Information available in the literature $[5,6,12,32$, $50]$ indicates that many factors underlie the selection of food products by Polish consumers. Among others, it has become prerequisite for many food businesses, for the development and marketing of new products, that they satisfy the ever-increasing consumer knowledge on the relationship between diet and health. According to Bialoskurski, the concept of "new" food product development is recognized by consumers primarily as a product that is upgraded to meet the new needs and modified in various ways [12].
Polish consumers are increasingly showing their interest toward food products featuring sensory and health properties as well as safety. The findings of the study of Ozimek and Żakowska-Biemans [50] indicate at the same time that the perception regarding quality of food is dependent on the evaluated product and its place of purchase. Food products dedicated to specific groups of consumers (e.g., infants and people struggling with health problems) are perceived to be possessing high quality. On the other hand, food products with food additives and which are highly processed and genetically 
modified are more often considered to be of low quality. In the context of the above findings, it has been noticed that attitude toward food and the ability to classify it as "healthy" and "unhealthy" are developed from an early age onward. Such a subjective classification of foods can be misleading because of a lack of nutritional knowledge. Therefore, the role of the food industry seems to be invaluable, because due to the production of a large range of highly processed products, on the one hand, it is responsible for public health, while on the other, it has to modify its product according to the current dietary recommendations [50,91].

In response to the market demand, food producers, including meat sector companies, are undertaking various initiatives that are aimed at diversifying their commercial product, and at the same time adapting it to the current market trends. One of such activities is the so-called "clearing" of food labels. Although the term "clean label" is already mentioned on different products and has appeared more frequently in literature in recent years, no common objective and legally binding definition of "clean label" for a food product has been developed so far [8].

Consumers generally assess the quality of a product and the "cleanliness and clarity" of its label through the packaging information (or information accompanying it during the sale). The results of research indicate that the choice of a "clean label" food product is dependent on a number of factors, most important among them being health consciousness and a desire to lead a healthy lifestyle. There has been an increasing interest among the inhabitants of industrialized countries to know the ingredients of the food they consume, its nutritional value, and the bioavailability of various nutrients, as well as food production methods. Most people have a negative perception with regard to intensive farming, which involves extensive processing of food and excessive "chemization," since they believe that the food products produced by this technique negatively affect the health of consumers. This problem also applies to meat and meat products [47]. Moreover, there are growing concerns about the impact of food production methods on environmental sustainability and climate changes. These demands have prompted the search for less processed, more "natural" products that contain no synthetic food additives, and hence are considered to be "healthier." Foods that meet the above-mentioned criteria are referred to as "clean label" products [9].

The results of a recent consumer research study indicate that interpretation of the term "clean label" is largely subjective, because it depends on the consumer's knowledge of both health and food production. Consumer behavior confirms the tendency to avoid buying food which in their opinion does not meet the adopted criteria or expectations. This is called "negative attitude." Taking the above factors into consideration, it seems that the key to successful selling of food product with the so-called "clean label" is the manner in which the food information is provided $[1,8]$.

In European Union, issues relating to the labeling of food products are regulated by food law (Table 1). Polish requirements in this area are designed based on the EU legislation guidelines, which establish the general principles, requirements, and obligations regarding the provision of food information to consumers. The food product label is a kind of platform for communicating with the consumer and providing him the food information. The provisions of Regulation (EU) No 1169/2011 indicate which information is mandatory on the product label and which may be provided voluntarily. In the light of the above provisions, statements such as "clean label," "natural product," and "no artificial food additives" are non-compulsory. When placing them, the food business operator responsible for the food information (i.e., the operator under whose name or business name the food is marketed or if that operator is not established in the EU, the importer into the Union market) cannot mislead the consumer.

Consumers accept the fact that the price of a product with a "clean label" may be higher than that of its "conventional" counterpart. Not everyone, however, realize that low-processed products, often described as "natural," "traditional," with "improved health value," do not have to be produced using organic farming methods or old production technologies; they can be successfully manufactured using the conventional food processing techniques [8].

Products with improved health quality, including nutritional value, represent a fairly wide group of innovative food products on the Polish market. Under certain conditions, they may also be called as functional foods. The study of consumer attitudes and behavior toward various forms of functional foods have shown that health-promoting values of food are appreciated mainly by people interested in their own health and families (especially women) [9]. In the opinion of Polish female consumers, in order to obtain meat of better health quality, one should use natural methods of animal husbandry, in particular an appropriate way of taking care of their health, feeding, and keeping (so-called "free-range"); subject them to humane slaughter; and use an appropriate method for pretreatment, storage, and distribution of meat products [32].

The variables affecting the consumption of meat products with improved health quality and consumers' buying habits were, among others, the following: own assessment of the health benefits associated with the diet, identification of special nutritional needs, health and nutrition information on food labels, product type, having prior knowledge about the product, and new product 
concept. The consumers showed high uncertainty toward consumption of meat products with improved health value. However, the respondents showed a positive attitude toward concepts which involved modification of the recipe composition, such as reducing the content of salt (sodium chloride) and fat, and replacing sodium nitrate (III) with ingredients of natural origin. A skeptical opinion was expressed with regard to the addition of "healthier" ingredients to meat products, such as n-3 polyunsaturated fatty acids and vitamin $\mathrm{E}[75,76]$.

Many studies [3, 7, 21, 22, 23, 36, 46, 80, 81, 95] concerning the methods to improve the health quality and nutritional value of meat and meat products have been published. More information on concepts aimed at improving the health quality of meat and meat products is presented in Table 2 .

Table 2. Concepts to improve health quality of meat and meat products and examples of activities in this field

\begin{tabular}{|c|c|c|}
\hline \multicolumn{3}{|c|}{ Concepts to improve health quality of meat and meat products } \\
\hline $\begin{array}{l}\text { Modification of animal carcass } \\
\text { composition }\end{array}$ & $\begin{array}{l}\text { Changes in the recipe composition of } \\
\text { meat products }\end{array}$ & $\begin{array}{l}\text { Changes in the production process } \\
\text { and in technology }\end{array}$ \\
\hline $\begin{array}{l}\text { - Reduction of fat content }[39,87] \\
\text { - Lowering the cholesterol content }[19] \\
\text { - Change in the profile of fatty acids } \\
\text { [41] } \\
\text { - Increasing the content of certain min- } \\
\text { erals }[35,54] \\
\text { - Increasing the content of antioxi- } \\
\text { dants and vitamins }[31,79,88]\end{array}$ & $\begin{array}{l}\text { - Reduction of fat content [29] } \\
\text { - Change in the profile of fatty acids }[4,16] \\
\text { - Elimination of allergenic ingredients [90, } \\
\text { 92] } \\
\text { - Incorporation of certain ingredients into } \\
\text { product recipe composition to obtain } \\
\text { beneficial effects on health }[52,55] \\
\text { - Addition of probiotics and prebiotics }[18, \\
24,38,86,93]\end{array}$ & $\begin{array}{l}\text { - Reduction of nitrate (III) content in } \\
\text { favor of the ingredients of natural } \\
\text { origin }[2,10,44,82] \\
\text { - Eliminating traditional smoking } \\
\text { method and replacing it with smoke } \\
\text { preparations [43, 78, 89] } \\
\text { - Biopreservation [40] }\end{array}$ \\
\hline
\end{tabular}

The range of potential buyers of meat products with improved health benefits is very broad, and therefore the market for these products has been steadily growing. In addition to growing interest and market demand for meat products with improved nutritional value and health quality, stimulated through, among others, the campaigns of nutrition societies and experts of international organizations in the field of human nutrition and medicine, it is worth emphasizing the importance of the initiatives undertaken by the producers themselves. In recent years, the meat industry has developed and implemented a number of strategies aimed at improving the health value of the products offered, ranging from measures adopted in the area of animal production, through the processing of raw material and design of product composition, to the selection of appropriate storage conditions and preparation of the final product for consumption. For example, in Europe, the producers of meat products have been focusing for several years on expanding the market by offering products with reduced content of table salt $[36,84]$ and fat [83]. Relevant information to facilitate the identification of such products is included in the form of statements on their packaging or labels.

Functional food is being discussed in Europe in the context of nutrition and health claims provided on the labels of individual packages of food products [42]. The list of food claims authorized for use in the EU and harmonized rules for their use are regulated by Regulation (EC) No 1924/2006, as amended (Table 1). The types of food claims and examples thereof are summarized in Table 3.

Table 3. Types of food claims and examples thereof according to the Regulation (EC) No 1924/2006

\begin{tabular}{|l|l|}
\hline \multicolumn{1}{|c|}{ Nutrition claim - definition } & \multicolumn{1}{|c|}{ Nutrition claim - examples } \\
\hline $\begin{array}{l}\text { "Nutrition claim" means any claim which states, suggests, } \\
\text { or implies that a food has particular beneficial nutritional } \\
\text { properties due to: (a) the energy (calorific value) it (i) } \\
\text { provides, (ii) provides at a reduced or increased rate, or } \\
\text { (iii) does not provide; and/or (b) the nutrients or other } \\
\text { substances it (i) contains, (ii) contains in reduced or } \\
\text { increased proportions, or (iii) does not contain }\end{array}$ & $\begin{array}{l}\text { "High protein" } \\
\text { "Salt-free" } \\
\text { "Source of fiber" }\end{array}$ \\
\hline \multicolumn{1}{|c|}{ Health claim-definition } & \multicolumn{1}{c|}{ Health claim-examples } \\
\hline $\begin{array}{l}\text { "Health claim" means any claim that states, suggests, or } \\
\text { implies that a relationship exists between a food category, } \\
\text { a food product, or one of its constituents and health }\end{array}$ & $\begin{array}{l}\text { "Beta-glucans contribute to the maintenance of normal } \\
\text { blood cholesterol levels" } \\
\text { "Replacing saturated fats in the diet with unsaturated fats } \\
\text { contributes to the maintenance of normal blood cholesterol } \\
\text { levels. Oleic acid is an unsaturated fat" }\end{array}$ \\
\hline
\end{tabular}


Producers quite often display the claims in the food labels to highlight the characteristics of the product or the health benefits associated with its consumption [ 42 , 51]. The message available in the claim is an easily available source of information about the product and can facilitate the decision to buy it. However, the presence of a claim is not always reflected in the intent to purchase the product. The credibility of both types of statements is comparable, although consumers rate the health claims slightly better than the nutritional claims [77].

It is now evident that consumers prefer food products with a "clean label" because of the lack of negatively perceived ingredients, such as allergenic substances or food additives which sound like chemical names. Instead, products with a "simple" composition are preferred, i.e., containing only the necessary ingredients that consumers know and perceive as natural and associate with a product based on a traditional recipe. When looking for a "clean label," many consumers avoid products with ingredients which are unknown to them or are, in their opinion, only unnecessary food additives [1].

According to consumers, food additives are defined as both additives authorized for use in food and ingredients added to food products during processing. In the Member States of the European Union, the use of food additives is regulated by law. The scientific evaluation of food additives proposed for use in food products is carried out by the European Food Safety Authority (EFSA). Scientific opinions prepared by EFSA constitute the basis for the development of legal regulations in this field.

The definition of "food additive" has changed over time, since its first formulation in 1995 by the joint committee of FAO/WHO expert [14]. In the light of the opinion of EFSA and the Food and Drug Administration (FDA) of the United States, food additives are intentionally introduced into food to obtain the intended effect, and as a result become its components. In Europe, food additives are marked with the letter E and a sequence number. Food additives include a large group of chemical compounds. They can be divided based on various criteria, most common among them being origin (natural, identical to natural, and synthetic) and basic function (e.g., preservatives, coloring agents, flavoring agents, texturizing agents, nutritional additives, and miscellaneous agents) $[14,15]$.

Food ingredients are not considered as food additives, according to Regulation (EC) No 1333/2008 (Table 1). However, they are intentionally added during the production of a food product, in accordance with the principles of Good Manufacturing Practice. Their use does not raise - according to the current state of knowledge - health concerns, which is expressed, inter alia, by not marking them with the letter E. A few examples of such substances used in meat processing are table salt, soy protein, potato starch, and gelatin.

Despite the fact that the addition of food additives confers benefits to the food products, such as improving quality, extending consumer durability, and reducing manufacturing costs, consumer attitudes toward food additives have mostly been unfavorable. Increased knowledge about healthy lifestyle has led to increased concerns about the quality of food with a long list of additives. In addition, the European terminology of food additives (E number) and the strange-sounding "chemical" names of many of them do not support their acceptance $[8,49]$.

Contrary to the concerns of some consumers, a food additive may be included in the EU lists available in Annexes II and III of Regulation (EC) No 1333/2008 only if at the proposed level of use it does not pose a threat to consumer health and its presence in food does not mislead the consumer. Fulfillment of the condition that there is no risk to consumer health is ensured by the EFSA's safety assessment of the food additives. EFSA's reevaluation program regarding the safety of food additives that were authorized in the EU before January 20, 2009 is currently underway. This program has been published in Commission Regulation (EU) No 257/2010 [20]. It covers 316 substances and the report should be completed by December 31, 2020. The criteria on the basis of which the order of the reevaluation of individual groups of food additives was adopted were, among others, availability of new scientific evidence, scope for use of a given substance in food, and data on the consumption of food additives in the $\mathrm{EU}[20,27,28]$. Some decisions on the use of relevant food additives in the meat industry, taken by the European Commission based on the safety reevaluation carried out by EFSA, are presented in Table 4.

In the light of the above-mentioned findings, food producers are taking various actions to improve the quality of their products according to the "clean label" trend. One of them is product reformulation, i.e., modifying the recipe composition in terms of the possibility of eliminating synthetic food additives. For products containing food additives of natural origin or identical to natural ones, it may be a good option to add its name in the food label which in turn can exert a positive impact on consumers (e.g., "potato starch"). A change in the attitude of consumers to a "disliked" or unknown food additive or food ingredient may also be addressed by explaining its role in the product and / or indicating consumer-oriented benefits on the food label. Such benefits may include higher content of one or more nutrients or vitamins, more desirable texture, color stability, longer shelf-life of the product, etc. [1]. 
Table 4. Some decisions on food additives taken by the European Commission based on safety reevaluation carried out by EFSA $[27,28]$

\begin{tabular}{|c|c|}
\hline Food additive number and name [function] & Decision on the use of the food additive [EFSA opinion] \\
\hline E128 Red 2G [food synthetic color] & $\begin{array}{l}\text { The application of E128 in food has been suspended and } \\
\text { justified by the potential genotoxic effects of one of the } \\
\text { derivatives of metabolism [48] }\end{array}$ \\
\hline $\begin{array}{l}\text { E102 Tartrazine, E104 Quinoline yellow, E110 Sunset } \\
\text { Yellow FCF, E122 Azorubine/Carmoisine, E124 } \\
\text { Ponceau 4R, E129 Allura Red AC [food synthetic } \\
\text { colors, the so-called “Southampton colors”] }\end{array}$ & $\begin{array}{l}\text { Since July } 2010 \text {, food labels should contain a warning if } \\
\text { the product contains at least one of the six colorants from } \\
\text { Southampton study: "May have an adverse effect on activity } \\
\text { and attention in children" }[62,63,64,65,66,67]\end{array}$ \\
\hline $\begin{array}{l}\text { E } 120 \text { Cochineal, carminic acid, carmines [food } \\
\text { natural and identical to natural colors] }\end{array}$ & $\begin{array}{l}\text { The name of E120 was changed to "carminic acid, carmines"; } \\
\text { new specifications have been established for cochineal extracts } \\
\text { ("carminic acid" is an aqueous, alcoholic, or aqueous-alcoholic } \\
\text { extract of cochineal) and "carmine," i.e., hydrated aluminum } \\
\text { chelates (lakes) of carminic acid [71] }\end{array}$ \\
\hline $\begin{array}{l}\text { E150a-E150d Caramel colors [identical to natural } \\
\text { colors] }\end{array}$ & $\begin{array}{l}\text { The value of the accepted daily intake }(\mathrm{ADI}) \text { for all four } \\
\text { caramel colors was set at } 0-300 \mathrm{mg} / \mathrm{kg} \text { body weight } \times \text { day, } \\
\text { including the individual ADI value for E150c ammonia } \\
\text { caramel at } 0-100 \mathrm{mg} / \mathrm{kg} \text { body weight } \times \text { day [68] }\end{array}$ \\
\hline $\begin{array}{l}\text { E620 Glutamic acid and salts thereof (E621-E625) } \\
\text { [flavor enhancers] }\end{array}$ & $\begin{array}{l}\text { The value of the ADI for glutamic acid and its salts (total intake } \\
\text { E620-E625) was set at } 0-30 \mathrm{mg} / \mathrm{kg} \text { body weight } \times \text { day [74] }\end{array}$ \\
\hline $\begin{array}{l}\text { E311 Octyl gallate, E312 dodecyl gallate } \\
\text { [antioxidants] }\end{array}$ & $\begin{array}{l}\text { E311 and E312 have been removed from the list of permitted } \\
\text { food additives }[69,70]\end{array}$ \\
\hline $\begin{array}{l}\text { E249 Potassium nitrite, E250 sodium nitrite, E251 } \\
\text { sodium nitrate, E252 potassium nitrate [food } \\
\text { preservatives] }\end{array}$ & $\begin{array}{l}\text { The current ADI values have been maintained at previous levels } \\
\text { for nitrites and nitrates; the need to regulate the use of vegetable } \\
\text { extracts containing nitrates and nitrites for meat preparations } \\
\text { instead of curing salt has been emphasized }[72,73]\end{array}$ \\
\hline
\end{tabular}

Like other industries, the meat industry, in response to market demand, is trying to limit the use of food additives by eliminating them from the formulation of various products or replacing them with ingredients of natural origin. On the labels of meat products (mainly smoked meats and sausages), one can see information placed by producers, which takes form of claims or declarations, e.g., "without the addition of monosodium glutamate," "without the addition of phosphates," "without added preservatives." At the same time, to ensure safety and sufficient shelf-life and maintain high sensory attributes of meat products, producers have resorted to solutions such as the use of spice preparations or yeast extract to improve palatability, the use of plant (e.g., soy protein or lupine protein) or animal (e.g., sodium caseinate or collagen protein) preparations to maintain the desired structure and production efficiency, as well as the use of plant extracts rich in nitrates $(\mathrm{V})$ together with bacterial denitrifying cultures to give the sausages a pink-red, durable color. The above measures simultaneously serve to improve the nutritional value of meat products, as mentioned earlier. Market information indicates that Polish producers of meat preparations are also implementing procedures to improve the quality of their products. For example, allergenic ingredients and food additives are eliminated from the product composition $[25,56]$.

Substances or products that are known to cause allergies or intolerances are other food ingredients that are increasingly avoided by consumers. The aim of the work of Cegietka and Mańkowska was to assess the presence of allergenic components in the selected technological groups of meat products, i.e., cooked and raw smoked meats as well as raw and thermally processed sausages, which were available in retail trade in Warsaw. Based on the information provided by the producers on the product packaging (product labels), it was found that substances or products causing allergies or intolerances were found in $45 \%$ of meat products. The possible presence of allergens was demonstrated in $30 \%$ of the products, and information on the presence of allergens among the ingredients of the product was provided on the packaging of $14 \%$ of all products. The availability of meat products free of allergens is much less (11\% of all products). The greater number of substances causing allergies was found in sausages than in smoked meats. Irrespective of the technological group of meat products assessed, the most commonly used components that may cause allergic reactions in consumers were soybeans, mustard, and milk and products thereof [17]. 


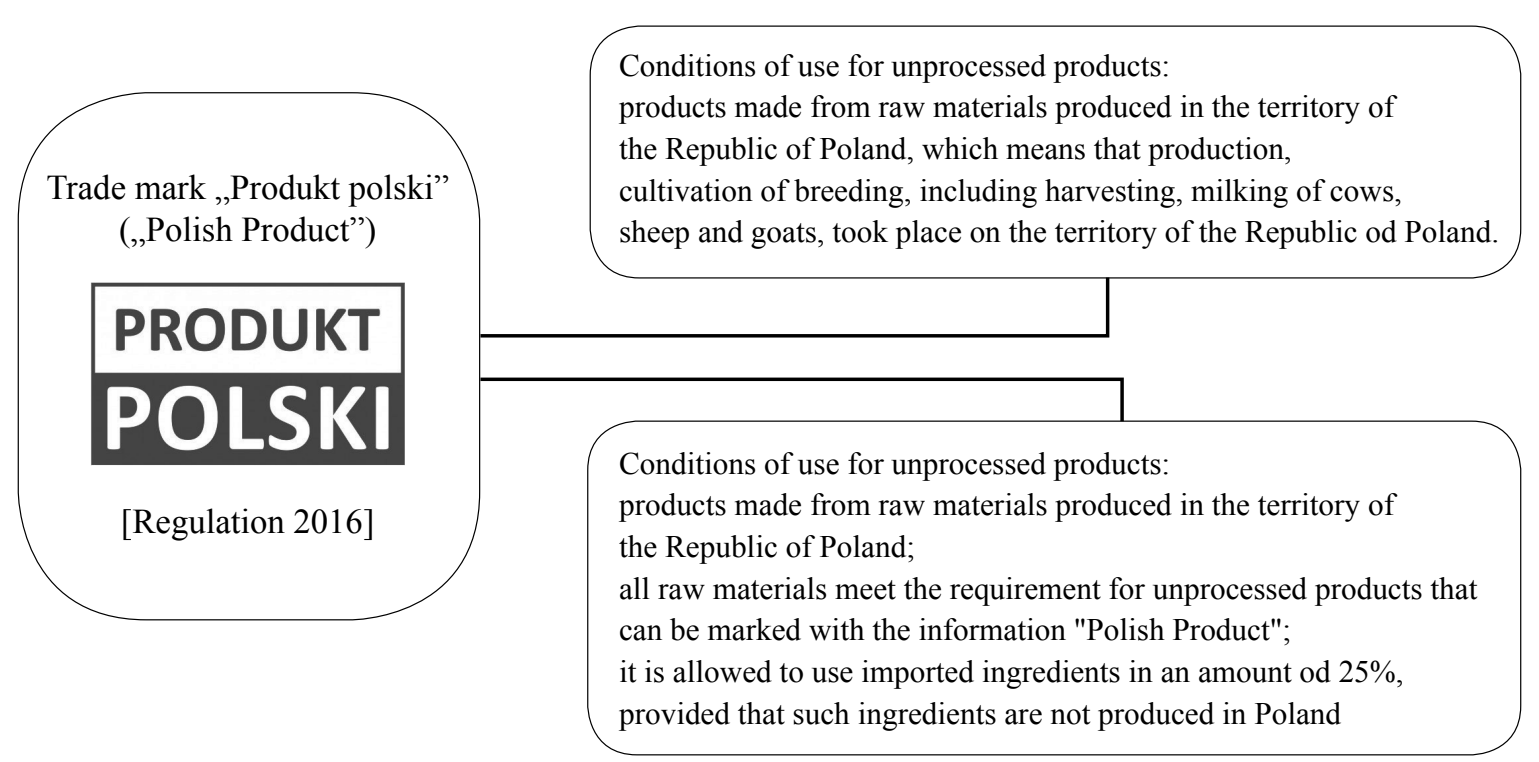

Figure 2. The "Polish product" mark and conditions of its use [59].

The production of food with controlled allergenicity can be of significant importance to face market competition and may contribute to building a positive and well-associated image of the manufacturer, by not only satisfying the requirements of high-quality products, but also caring for the health of the buyers of their products. The fact that such undertakings are possible in the meat processing industry was confirmed by a team of scientists from the Warsaw University of Life Sciences (SGGW) and the Institute of Genetics and Animal Breeding of the Polish Academy of Sciences [90], who obtained a patent entitled "A method for producing pork meat products with controlled allergenicity". The proposed innovative method for the production of meat products with reduced allergenicity and increased content of selenium and polyunsaturated fatty acids is characterized by the appropriate selection of raw material, functional additives, and the technology of their production. Similar activities of Polish producers in meat preparations are financially supported by the EU from the European Regional Development Fund [25].

For a growing number of consumers, the concept of healthy lifestyle has attributed to a growing interest in organic foods (also referred to as "biofoods" or "ecological foods"). The use of organic raw materials in food production is sometimes equated with "cleaning" the label. Organic food is in fact a product of organic farming (Figure 1), defined as a system which involves plant and animal production based on environment-friendly practices, by adapting to the local conditions and biodiversity [61].

Consumers are convinced that organic products are healthier than conventional foods and are characterized by high quality, absence of harmful pesticides, high nutrient value, etc. $[57,58,61]$. The use of organic raw materials in food processing techniques usually indicates that the finished product does not contain food additives or contains only those necessary for its production. This concept of a food product thus corresponds to the idea of a "clean label" [8].

The consumers' interest in ecological methods of food production has increased significantly in Poland following the accession of this country to the EU $[32,60]$. According to a study by Dolatowski [23], lesser interest in meat and meat products produced organically, in comparison with other food groups, resulted in relatively low supply, high prices, and unsatisfactory quality. However, according to Salejda and Krasnowska [61], Polish consumers are aware of the benefits of organic farming and hence are prepared to compromise for a higher price and slightly lower sensory features of smoked meats and sausages, which they most often purchase.

Another aspect of understanding the "clean label" of food products maybe - apart from the desire to know the method of production - to know the place of its manufacture. This behavior is typical for ethnocentrically oriented consumers, being the opposite of global consumers. In people in whom globalization has not weakened their ties with the country or region of residence, or the sense of national and local identity, increased interest in national and local products is being observed. The ethnocentric consumer is convinced with the advantage of domestic products over foreign ones, which in turn is guided by rational and emotional criteria when choosing them [5]. The BEUC [11] study showed that in countries such as Austria, France, Poland, and Sweden, nearly $70 \%$ of consumers considered the origin of meat as an important factor in purchasing it. For processed foods - of both plant and animal origin - the majority of respondents would want to easily identify the country of origin of both the primary ingredient and the final product. Finding such information was often troublesome for consumers $[11,26]$. In response to this demand, the new EU legislation on food labeling 
(Table 1) has extended the obligation to label origin of meat coming from beef to poultry, pigs, and sheep and strengthened the obligation to inform consumers about the place of processing of raw materials if the main component has different origin from the product itself.

In order to meet the expectations of consumers in Poland regarding easier identification of products made from Polish raw materials and by Polish manufacturers, the Ministry of Agriculture and Rural Development developed rules for using the information and the "Polish product" mark (Figure 2). In Poland, labeling of food products with the information and the "Polish product" mark is voluntary and does not require registration. However, compliance of products marked with the "Polish product" mark with statutory criteria is subject to verification by the inspection services.

\section{CONCLUSIONS}

Identifying current trends and studying consumer behavior in an extremely diverse food market still seems necessary to better understand and, consequently, better tailor the market offer to its needs. One of the relatively new and still current direction toward the development of food market is the concept of "clean label." Among the whole range of factors explaining consumer preferences regarding "clean labeling" of food, the results of previous studies emphasize in particular the characteristic features of the product and sociocultural factors determining the individual attitude of the consumer, primarily related to health. The "clean label" has not yet been defined in food law and is understood rather subjectively. Generally, this term is attributed to products free from "artificial" additives and produced organically or by "natural" methods based on a traditional recipe known to consumers. In the absence of a clear definition of the "clean label" for a food product, both producers and consumers perceive the need for its precise description. On the one hand, this would facilitate positioning of products on the market and communication of producers with consumers, while on the other hand, it would reduce the risk of consumers being misled about the expected quality features of food with the "clean label."

\section{Conflict of interest}

The author declare no conflict of interest.

\section{REFERENCES}

1. Achermann-Witzel J., Varela P., Peschel A.O.: Consumers' categorization of food ingredients: Do consumers perceive them as 'clean label' producers expect? An exploration with projective mapping. Food Qual Prefer 2019;71:117-128 doi: 10.1016/j.foodqual.2018.06.003.
2. Adamczak L., Florowski T., Dąbkowska A.: Porównanie jakości kiełbas drobno rozdrobnionych peklowanych tradycyjnie i z wykorzystaniem preparatu warzywnego jako źródła azotanów V [Comparison of the quality of frankfurter type sausages cured by traditional method or with addition of vegetable extract as a source of nitrates]. Nauka Przyroda Technologie 2010;4(5),\#53 (in Polish). Available http://www.npt.up-poznan.net/ pub/art_4_53.pdf (Accessed 10.08.2019).

3. Alahakoon A.U., Jayasena D.D., Ramachandra S., Jo $C$.: Alternatives to nitrite in processed meat: Up to date. Trends Food Sci Technol 2015;45:37-49 doi: 10/1016/j. tifs.2015.05.008.

4. Andrés S.C., Zaritzky N.E., Califano A.N.: Innovations in the development of healthier chicken sausages formulated with different lipid sources. Poult Sci 2009;88: 1755-1764.

5. Angowski M., Jarosz-Angowska A.: Local or imported product: Assessment of purchasing preferences of consumers on food markets - The case of Poland, Lithuania, Slovakia and Ukraine. In: Bilgin M., Danis H., Demir E., Can U. eds. Eurasian Business Perspectives. Eurasian Studies in Business and Economics, vol 11/2. Springer, Cham 2019 doi: 10.1007/978-3-030-18652-4_3.

6. Angowski M., Lipowski M.: Uwarunkowania wyboru produktów żywnościowych i miejsc ich zakupu [Choice of food products and their place of purchase]. Marketing i Rynek 2014;6:1-16 (in Polish).

7. Arihara K.: Strategies for designing novel functional meat products. Meat Sci 2006;74:219-229.

8. Asioli D.E., Aschemann-Witzel J., Caputto V., Vecchio R., Annunziata A., Noes T., Varela P.: Making sense of the "clean label" trends: A review of consumer food choice" behavior and discussion of industry implications. Food Res Int 2017;99:58-71 doi: 10.1016/j.foodres.2017.07.022.

9. Babicz-Zielińska E.: Wpływ czynników środowiskowych na wybór i spożycie żywności [Impact of the environmental factors on food choice and consumption]. Handel Wewnętrzny 2015;2(355):5-18 (in Polish).

10. Bagnowska A., Krala L., Nowak A., Oracz J.: Właściwości przeciwutleniające chitozanu w kiełbasach bez dodatku azotanu(III) [Antioxidant properties of chitosan in sausages without nitrate (III) added]. Zywn Nauk Technol Ja 2014; 4(95):173-187 (in Polish) doi: 10.15193/ZNTJ/2014/95/173-187.

11. BEUC. Where does my food come from? BEUC consumer survey on origin labelling on food. January 2013. BEUC The European Consumer Organization. Available https://www.beuc.eu/publications/201300043-01-e.pdf (Accessed 10.082019).

12. Białoskurski S.: Postrzeganie wybranych kryteriów innowacyjności produktów spożywczych przez konsumentów [Consumers' perception of selected criteria of food product innovation]. Zywn Nauk Technol Ja 2016;5(108):140-153 (in Polish) doi: 10.15193/ zntj/2016/108/156.

13. Biesalski H.K.: Meat as component of healthy diet-are there any risks or benefits if meat avoided in the diet? Meat Sci 2005;70:509-524. 
14. Carocho M., Barreiro M.F., Morales P., Ferreira I.C.F.R.: Adding molecules to food, pros and cons: A review on synthetic and natural food additives. Compr Rev Food Sci Food Saf 2014;13(4):377-399 doi: 10.1111/1541-4337.12065.

15. Carocho M., Morales P., Ferreira I.C.F.R.: Natural food additives: Quo vadis? Trends Food Sci Technol 2015;45:284-295 doi: 10.1016/j.tifs.2015.06.007.

16. Cegietka A.: Zastosowanie olejów roślinnych i preparatów błonnikowych do produkcji burgerów z mięsa kurcząt [Application of plant oils and fiber preparations for the production of chicken burger]. Zywn Nauk Technol Ja 2012;3(82):88-100 (in Polish).

17. Cegietka A., Mańkowska M.: Ocena obecności alergenów w wędlinach dostępnych na rynku warszawskim [Assessment of the presence of allergens in meat products available on the Warsaw market]. Postępy Nauki i Technologii Przemysłu Rolno-Spożywczego 2019;74(1):30-44 (in Polish) Available https://www. ibprs.pl/wp-content/uploads/2019/08/PNiTPRS-2019nr-1-Rozdzial3.pdf (Accessed 10.09.2019).

18. Cegietka A, Tambor K.: Effect of inulin on the physical, chemical and sensory quality attributes of polish chicken burgers. J Food Res 2010;1(1):169-178.

19. Clarke A.D.: Reduction of cholesterol levels in meat, poultry and fish products. In: Pearson A.M., Dutson T.R. eds. Production and Processing of Healthy Meat, Poultry and Fish Products. Advances in Meat Research, vol 11. Springer, Boston, MA, 1997.

20. Commission Regulation (EU) No 257/2010 of 25 March 2010 setting up a programme for the re-evaluation of approved food additives in accordance with Regulation (EC) No 1333/2008 of the European Parliament and of the Council on food additives. Off J EU L 80, 26.3.2010.

21. Decker E.A., Park Y.: Healthier meat products as functional foods. Meat Sci 2010;86:49-55 doi: 10.1016/j.meatsci.2010.04.021.

22. Desmond E.: Reducing salt: A challenge for the meat industry. Meat Sci 2006;74:188-196 doi:10.1016/j. meatsci.2006.04.014.

23. Dolatowski Z.: Prowadzenie badań w przetwórstwie produktów roślinnych, zwierzęcych metodami ekologicznymi [Conducting research in the processing of plant and animal products produced organically]. W: Streszczenia wyników badań z zakresu rolnictwa ekologicznego realizowanych w 2009 roku. MRiRW, Warszawa, 2010 (in Polish), Available https://www. gov.pl/web/rolnictwo/wykaz-tematow-badawczychi-streszczenie-wynikow-badan-z-zakresu-rolnictwaekologicznego-realizowanych-w-2009-roku (Accessed 10.08.2019)

24. Dolatowski Z.J., Kołożyn-Krajewska D.: Probiotyki w produkcji przetworów mięsnych [Probiotics in the production of meat products]. Gospodarka Mięsna 2011;4:14-21 (in Polish).

25. Fundusze Europejskie „Opracowanie i wdrożenie technologii wytwarzania wygodnych drobiowych w warstwie chrupkiej otoczki o kontrolowanej alergenności”. Available https://wierzejki.pl/?fundusze-europejskie (Accessed 10.08.2019)
26. Font-i-Furnols M., Guerrero L.: Consumer preference, behavior and perception about meat and meat products: An overwiev. Meat Sci 2014;98:361-371 doi: 10.1016/j. meatsci.2014.06.025.

27. Gajda-Wyrębek J.: Ponowna ocena substancji dodatkowych przez EFSA i jej konsekwencje dla branży mięsnej. [Re-evaluation of food additives by EFSA and its consequences for the meat industry] Materiały Konferencyjne 51. Dni Przemysłu Mięsnego pt. „Perspektywy zmian prawa żywnościowego w zakresie znakowania produktów mięsnych i stosowania dozwolonych substancji dodatkowych" oraz Sympozjum Naukowo-Techniczne pt. „Postęp w Technologii Mięsa. NaukaPraktyce", Warszawa, 16 maja 2019 r., 7-14 (in Polish).

28. Gajda-Wyrębek J., Jarecka J.: Ocena bezpieczeństwa substancji dodatkowych przez Europejski Urząd ds. Bezpieczeństwa Żywności [Safety assessment of food additives by European Food Safety Authority]. Hygeia Publ Health 2017;52(1):16-20 (in Polish).

29. García M.L., Dominguez R., Galvez M.D., Casas C., Selgas M.D. Utilization of cereal and fruit fibres in low fat dry fermented sausages. Meat Sci 2002;60:227-236.

30. Główny Urząd Statystyczny: Rocznik Statystyczny Rolnictwa 2018. Available at: https://stat.gov.pl (Accessed: 17.02.2020) (in Polish).

31. Grashorn M.A.: Geflügenfleisch als Functional Food. Anreicherung mit Konjugierter Linolsäure, Omega3-Fettsäure und Selen sowie Auswirkung auf die Produktqualität. Fleischwirtschaft 2006; 86(2):100 103.

32. Gutkowska K., Kowalczuk I., Sajdakowska M., Żakowska-Biemsns S., Kozłowska A., OlewnikMikołajewska A.: Postawy konsumentów wobec innowacji na rynku żywności [Consumers' Attitudes towards Innovations in the food market]. Handel Wewnętrzny 2014;4(351):80-93 (in Polish).

33. Górska-Warsewicz H.: Żywność wygodna w sektorze mięsnym. Przemysł Spożywczy 2007;61(4):36-38.

34. Grochowicz J., Fabisiak A., Nowak D. Market of functional food - legal regulations and development perspectives. Zeszyty Problemowe Postępów Nauk Rolniczych 2018;595:51-67 doi: 10.22630/ ZPPNR.2018.595.35.

35. Hess J.B., Downs K.M., Bilgili S.F.: Selenium nutrition and poultry meat quality. Poultry Indsustry 2007. Available https:/en.engormix.com/poultry-industry/ articles/selenium-nutrition-poultry-meat-t33625.htm (Accessed 10.08.2019).

36. Inguglia E.S., Zhang Z., Tiwari B., Kerry J.P., Burgess K.M.: Salt reduction strategies in processed meat products-A review. Trends Food Sci Technol 2017;59:70-78 doi: 10.1016/j.tifs.2016.10.016.

37. Kędzior $W$.: Substancje dodatkowe w przetwórstwie mięsa i warunki ich stosowania [Food additives in meat processing and their conditions of use]. Zesz Nauk, Uniwersytet Ekonomiczny w Krakowie, 2014;3(927):9-20 (in Polish).

38. Libera J., Dolatowski Z.J.: Wpływ bakterii probiotycznych Lactobacillus acidophilus (Bauer) i Bifidobacterium bifidum na zmiany thuszczu w mięsnych wyrobach surowo 
dojrzewających podczas przechowywania [Effect of Lactobacillus acidophilus (Bauer) and Bifidobacterium bifidumon probiotic bacteria on changes in fat in dryfermented meat products during storage]. Zywn Nauk Technol Ja 2014;4(95):160-1720 (in Polish).

39. Litwińczuk Z., Domaradzki P., Grodzicki T., Litwińczuk A., Florek M.: The relationship of fatty acid composition and cholesterol content with intramuscular fat content and marbling in the meat of Polish Holstein-Friesian cattle from semi-intensive farming. Anim Sci Pap Rep 2015;33(2):119-128.

40. Łaszkiewicz B., Szymański P., Kołożyn-Krajewska $D$.: Wpływ wybranych szczepów bakterii kwasu mlekowego na przydatność technologiczną i jakość mikrobiologiczną mięsa drobiowego oddzielonego mechanicznie [Effect of selected lactic acid bacteria on physicochemical characteristics and microbiological quality of mechanically separatek poultry meat]. ZywnNauk Technol Ja 2019;26(3):122-134 doi: 10.15193/ zntj/2019/120/302 (in Polish).

41. Mapiye C., Aalhus J.L., Turner T.D., Rolland D.C., Basarab J.A., Baron V.S., McAllister T.A., Block H.C., Uttaro B., Lopez-Campos O., Proctor S.D., Dugan M.E.R.: Effects of feeding flaxseed or sunflower-seed in high-forage diets on beef production, quality and fatty acid composition. Meat Sci 2013;95:98-109 doi: 10.1016/j.meatsci.2013.03.033.

42. Martínez S.V., Siani A.: Health claims made on food in the EU: The edge between scientific knowledge and regulatory requirements. Trends Food Sci Technol 2017;69:315-323 doi: 10.1016/j.tifs.2017.01.005.

43. Martinez O., Salmeron J., Guillen M.D., Casas C.: Texture profile analysis of meat products treated with commercial liquid smoke flavourings. Food Control 2004;15:457-461.

44. Martirosyan D.M., Singh J.: A new definition of functional food by FFC: what makes a new definition unique? Functional Foods in Health and Disease 2015;5(6):209-223.

45. Modzelewska-Kapituła M.: Effects of tomato powder on color, lipid oxidation and sensory properties of comminuted meat products. J Food Quality 2012;35(5):323-330 doi: 10.1111/j.17454557.2012.00457.x.

46. Olmedilla-Alonso B., Jiménez-Colmenero F., SánchezMuniz J.: Development and assessment of healthy properties of meat and meat products designed as functional foods. Meat Sci 2013;95:919-930 doi:1 0.1016/j.mettsci.2013.03.030.

47. Olszak J.: Clean label-nowy kierunek w znakowaniu żywności [Clean label-the new trend in food labeling]. Przemysł Spożywczy 2012;66(5):7-9 (in Polish)

48. Opinion of the Scientific Panel on Food Additives, Flavourings, Processing Aids and Materials in Contact with Food on the food colour Red 2G (E128) based on a request from the Commission related to the reevaluation of all permitted food additives. EFSA J 2007;515:1-28 doi: 10.2903 / j.efsa.2007.515.

49. Osborne $S$.: Labelling relating to natural ingredients and additives. In: Berryman P. Advances in Food and Beverage labeling: Information and regulations. Woodhead Publishing is an imprint of Elsevier, 2015.

50. Ozimek I., Żakowska-Biemans S.: Determinants of Polish consumers' food choices and their implication for the national food industry. Br Food J 2011:113(1): 138-154 doi: 10.1108/00070701111097394.

51. Ozimek I., Przeździecka-Czyżewska N.: Oświadczenia żywieniowe i zdrowotne w regulacjach prawnych i opinii konsumentów [Nutrition and health claims in legal regulations and opinions of consumers]. ZywnNauk Technol Ja 2017;1(110):5-17 doi: 10.15193/ zntj/2017/110/169 (in Polish).

52. Pentado T., Herrero A.M., Jiménez-Colmenero F., RuizCapillas C.: Strategies for incorporation of chia (Salvia hispanica L.) in frankfurters as a health-promoting ingredient. Meat Sci 2015;114:75-84 doi: 10.1016/ j.meatsci.2015.12.009.

53. Pereira P.M.C.C., Vincente A.F.R.B.: Meat nutritional composition and nutritive role in the human diet. Meat Sci 2013;93:586-592 doi: 10.1016/j.meatsci.2012.09.018.

54. Perić L., Milošević N., Žikić D., Kanački Z., Džinić N., Nollet L., Spring P.: Effect of selenium sources on performance and meat characteristics of broiler chickens. The J App Poultry Res 2009;18:403-409 doi: 10.3382/japr.2008-00017.

55. Petersson K., Godard O., Eliasson A.C., Tornberg $E$.: The effects of cereal additives in low-fat sausages and meatballs. Part 2: Rye bran, oat bran and barley fibre. Meat Sci 2014:96:503-508 doi: 10.1016/ j.meatsci.2013.08.019.

56. Przegląd Handlowy.pl. Nowa linia wędlin 'Bez E' od Henryka Kani. Available https://www. przegladhandlowy.pl/4707/nowa-linia-wedlin-bez-eod-henryka-kani/ (Accessed 10.08.2019).

57. Raza S.A., Shah N., Nisar W.: Consumer buying behavior of organic food with respect to health and safety concerns among adolescents. Munich Personal RePEc Archive. 2019 Available https://mpra.ub.unimuenchen.de/93570/ (Accessed 10.08.209)

58. Rembiatkowska E., Badowski M.: Mięso z produkcji ekologicznej [Meat from organic farming]. Gospodarka Mięsna 2010;8:16-19 (in Polish).

59. Rozporządzenie Ministra Rolnictwa i Rozwoju Wsi z dnia 16 grudnia 2016 r. w sprawie wzoru znaku graficznego zawierającego informację „Produkt polski”. Dz U 2016, poz. 2148.

60. Sajdakowska M., Jankowski P., Gutkowska K., Guzek D., Żakowska-Biemsns S., Ozimek I.: Consumer acceptance of innovations in food: A survey among Polish consumers. J Consum Behav 2018;17:253-267 doi: 10.1002/cb.1708.

61. Salejda A.M., Krasnowska G.: Ocena wybranych wyróżników jakości oraz analiza spożycia ekologicznych przetworów mięsnych [Evaluation of selected quality features and consumption analysis of organic meat products]. Nauka Przyroda Technologie 2014;8(1), \#7 (12 pages) (in Polish) Available https:// www.npt.up-poznan.net/pub/art 8_7.pdf (Accessed 10.08.2019). 
62. Scientific Opinion on the re-evaluation of allura Red AC (E129) as food additive. EFSA Panel on Food Additives and Nutrient Sources added to Food. EFSA J 2009;7(11),1327:1-39 doi: 10.2903 / j.efsa.2009.1327.

63. Scientific Opinion on the re-evaluation of ponceau 4R (E124) as a food additive. EFSA Panel on Food Additives and Nutrient Sources added to Food. EFSA J 2009;7(11):1328,1-39 doi: 10.2903 / j.efsa.2009.1328.

64. Scientific Opinion on the re-evaluation of quinoline yellow (E104) as a food additive. EFSA Panel on Food Additives and Nutrient Sources added to Food. EFSA J 2009;7(11),1329:1-40 doi: 10.2903 / j.efsa.2009.1329.

65. Scientific Opinion on the re-evaluation of sunset yellow FCF (E110) as a food additive. EFSA Panel on Food Additives and Nutrient Sources added to Food. EFSA J 2009;7(11),1330:1-44 doi: 10.2903 / j.efsa.2009.1330.

66. Scientific Opinion on the re-evaluation of tartrazine (E102) as a food additive. EFSA Panel on Food Additives and Nutrient Sources added to Food. EFSA J 2009; 7(11),1331:1-52 doi: 10.2903 / j.efsa.2009.1331.

67. Scientific Opinion on the re-evaluation of azorubine/ carmoisine (E122) as a food additive. EFSA Panel on Food Additives and Nutrient Sources added to Food. EFSA J 2009;7(11),1332:1-40 doi: 10.2903 / j.efsa.2009.1332.

68. Scientific Opinion on the re-evaluation of caramel colours (E150 a, b, c, d) as food additives. EFSA Panel on Food Additives and Nutrient Sources added to Food. EFSA J 2011;9(3),2004:1-103 doi: 10.2903 / j.efsa.2011.2004.

69. Scientific Opinion on the re-evaluation of dodecyl gallate (E312). EFSA Panel on Food Additives and Nutrient Sources added to Food. EFSA J 2015;13(5),4086:1-39 doi: 10.2903 / j.efsa.2015.4086.

70. Scientific Opinion on the re-evaluation of octyl gallate (E311) as a food additive. EFSA Panel on Food Additives and Nutrient Sources added to Food. EFSA J 2015;13(10),4248:1-39 doi: 10.2903 / j.efsa.2015.4248.

71. Scientific Opinion on the re-evaluation of cochineal, carminic acid, carmines (E120) as food additive. EFSA Panel on Food Additives and Nutrient Sources added to Food. EFSA J 2015;13(11),4288:1-65 doi: 10.2903 / j.efsa.2015.4288.

72. Scientific Opinion on the re-evaluation of potassium nitrite (E249) and sodium nitrite (E250) as food additives. EFSA Panel on Food Additives and Nutrient Sources added to Food. EFSA J 2017;15(6),4786:1-157 doi: 10.2903 / j.efsa.2017.4786.

73. Scientific Opinion on the re-evaluation of sodium nitrate (E251) and potassium nitrate (E252) as food additives. EFSA Panel on Food Additives and Nutrient Sources added to Food. EFSA J 2017;15(6),4787:1-157 doi: $10.2903 /$ j.efsa.2017.4787.

74. Scientific Opinion on the re-evaluation of glutamic acid (E620), sodium glutamiate (E621), potassium glutamate (E622), calcium glutamate (E623), ammonium glutamate (E624) and magnesium glutamate (E625) as food additives. EFSA Panel on Food Additives and Nutrient Sources added to Food. EFSA J 2017;15(7),4910:1-90 doi: 10.2903 / j.efsa.2017.4910.

75. Shan L.C., De Brún A., Henchion M., L C., Murrin C., Wall P.W., Monahan F.J.: Consumer evaluations of processed meat products reformulated to be healthier-A conjoint analysis study. Meat Sci 2017;131:82-89 doi: 10.1016/j.meatsci.2017.04.239.

76. Shan L.C., Henchion M., De Brún A., Murrin C., Wall P.W., Monahan F.J.: Factors that predict consumer acceptance of enriched processed meats. Meat Sci 2017:133:185-193 doi: 10.1016/j.meatsci.2017.07.00.

77. Shan C.L., Regan A., Monahan F.J., Li C., Murrin C., Lalor F., Wall G.W. McConnon A.: Consumer views on "healthier" processed meat. Br Food J 2016;118(7): 1712-1730 doi: 10.1108/BFJ-11-2015-0447.

78. Šimko P.: Factors affecting elimination of polycyclic aromatic hydrocarbons from smoked meat foods and liquid smoke flavorings. Mol Nutr Food Res 2005;49:637-647.

79. Skřivan M., Dlouhá G., Mašata O., Ševčíková S.: Effect of dietary selenium on lipid oxidation, selenium and vitamin $\mathrm{E}$ content in the meat of broiler chickens. Czech J Anim Sci 2008;53:306-311 Available https://pdfs. semanticscholar.org/fcab/698218e16edf110e079e60fea a12c576e781.pdf (Accessed 10.08.1019).

80. Słowiński M., Jankiewicz L.: Mięso i przetwory mięsne żywnością funkcjonalną - Część I. [Meat and meat products as functional foods-Part 1]. Gospodarka Mięsna 2011;4:10-13 (in Polish).

81. Stowiński M., Jankiewicz L.: Mięso i przetwory mięsne żywnością funkcjonalną - Część II. [Meat and meat products as functional foods-Part 2]. Gospodarka Mięsna 2011;5:18-22 (in Polish).

82. Sucu C., Turp G.Y.: The investigation of the use of beetroot powder in Turkish fermented beef sausage (sucuk) as nitrite alternative. Meat Sci 2018;140:158166 doi: 10.1016/j.meatsci.2018.03.012.

83. Świader K., Piotrowska A., Rachtan-Janicka A., Rembiatkowska E., Kostyra E., Dybkowska E., Wilk S.: Możliwości otrzymywania funkcjonalnych produktów $\mathrm{z}$ mięsa wieprzowego poprzez modyfikowanie technologii ich wytwarzania. [The possibility of obtaining functional products from pork meat by modifying the production technology]. Postępy Techniki Przetwórstwa Spożywczego 2017;1:128-135 (in Polish).

84. Tamm A., Bolumar T., Bajovic B., Toepfl S.: Salt $(\mathrm{NaCl})$ reduction in cooked ham by a combined approach of high pressure treatment and the salt replacer $\mathrm{KCl}$. Innov Food Sci Emerg Technol 2016; 36(8): 294-302 doi: 10.1016/j.ifset.2016.07.010.

85. Trajer M.: Rozwój rynku mięsnego w Polsce w 2018 r. [Development of the meat market in Poland in 2018]. Gospodarka Mięsna 2019;4, 48-50 (in Polish).

86. Trząskowska M., Kołożyn-Krajewska D., Wójciak K., Dolatowski Z.: Microbiological quality of rawfermented sausages with Lactobacillus casei LOCK 0900 probiotic strain. Food Control 2014;35:184-191 doi: 10.1016/j.foodcont.2013.07.002.

87. Vahmani P., Jon Meadus W., Uttaro B., López-Campos Ó., Mapiye C., Rolland D.C., Caine W.R., Aalhus J.L., Dugan M.E.R.: Effects of feeding beef fat enriched with polyunsaturated fatty acid biohydrogenation products to pigs. Can J Anim Sci 2016;96:95-99 doi: 10.1139/ cjas-2015-0080 
88. Vlahova-Vangelova D.B., Dragoev S., Balev D., Ivanova S., Nikolova T., Nakev J., Gerrard, D.: Improving the oxidative stability of pork by antioxidant type phytonutrients. AgriXiv Preprints 2019 doi: 10.31220/ osf.io/gz39p

89. Waszkiewicz-Robak B., Szterk A., Rogalski M., Kruk M., Rokowska E., Zarodkiewicz M., MikiciukJ.: Wpływ procesu wędzenia wyrobów wieprzowych otrzymanych z mięsa o różnej jakości początkowej na zawartość wielopierścieniowych węglowodorów aromatycznych [Effect of process of smoking meat products from pork showing with different initial quality on content of polycyclic aromatic hydrocarbons]. Zywn-Nauk Technol Ja 2014;2(93):73-92 (in Polish) doi: 10.15193/ zntj/2014/93/073-092.

90. Wierzbicka A., Gutkowska K., HorbańczukJ., GuzekD., Poławska E., Póltorak A., Marcinkowska-Lesiak M., Wyrwisz J., Tomasik C., Kuboń M.: Sposób wytwarzania wyrobów mięsnych wieprzowych o kontrolowanej alergenności. Patent PL 220814 B1. Wiad. Urzędu Patentowego 2016 Available https://grab.uprp.pl/ sites/WynalazkiWzoryUzytkowe/Opisy/Patenty\%20 i\%20Wzory\%20uytkowe/220814_B1.pdf (Accessed 10.08.2019).

91. Wierzejska R.: Informacje żywieniowe na opakowaniach produktów spożywczych - podejście konsumenta
[Nutritional claims on food labels-consumers'attitudes]. Przemysł Spożywczy 2012;66(5):43-45 (in Polish).

92. Wilson J.M., Platts-Mills T.A.E.: Meat allergy and allergens. J Mol Immunol 2018;100:107-112 doi: 10.1016 / j.molimm.2018.03.018.

93. Wójciak K.M., Dolatowski Z.J., Kołożyn-Krajewska D., Trzaskowska M.: The effect of the Lactobacillus casei LOCK 0900 probiotic strain on the quality of dry-fermented sausage during chilling storage. J Food Quality 2012;35:353-365 doi: 10.1111/j.17454557.2012.00458.x.

94. Wrześniewska-Wal I.: Prawne aspekty wprowadzania do obrotu żywności genetycznie zmodyfikowanej [Legal aspects of the marketing of genetically modified foods] Post Nauk Med 2009;4:310-316 (in Polish) Available http://www.czytelniamedyczna.pl/3115,prawne-aspektywprowadzania-do-obrotu-zywnoci-genetyczniezmodyfikowanej.html (Accessed 10.08.2019).

95. Zhang W., Ciao S., Samaraweera H., Lee E.J., Ahn D.U.: Improving value of meat products. Meat Sci 2010;86:15-31 doi: 10.1016/j.meatsci.2010.04.018.

Received:13.09.2019

Accepted:10.01.2020 